\title{
How The Nurses' Attitude for Dying Patients and Their Knowledge about Palliative Care?
}

\section{Hemşirelerin Ölmekte Olan Hastaya ilişkin Tutumları ve Palyatif Bakım Hakkındaki Bilgi Durumları Nasıldır?}

\author{
(i) Ahmet SEVEN1', id Havva SERT²
}

1Kahramanmaraş Sütçü İmam University, Afşin School of Health, Division of Nursing, Kahramanmaraş, Turkey

${ }^{2}$ Sakarya University Faculty of Health Sciences, Division of Internal Diseases Nursing, Sakarya, Turkey

\section{ABSTRACT}

Objective: To determine nurses' level of knowledge when it comes to palliative care as well as to investigate their attitudes regarding the care of terminally ill patients.

Methods: This descriptive and cross-sectional study was conducted with the voluntary participation of 350 nurses in three major hospitals affiliated to the General Secretariat of the Union of Public Hospitals of Sakarya. Data were gathered via a Self-description Form, the Frommelt Attitudes Toward Care of Dying scale (FATCOD), and Palliative Care Knowledge Test (PCKT), and analysis was conducted using percentages and average scores as well as the MannWhitney U, Kruskall-Wallis $\mathrm{H}$ and Pearson's correlation tests.

Results: The nurses, whose age average was 35.58 7.63 years, were predominantly female $(84.3 \%)$. More than half of them were married $(60.9 \%)$, nearly half of them were university graduates $(51.4 \%)$, and $62.9 \%$ of them work in Internal Diseases units. The nurses' average PCKT score was $6.35 \pm 3.31$ and their average FATCOD score was $77.98 \pm 8.81$. Marital status, level of education, and their employment units did not affect the attitudes towards death $(p>0.05)$ but they did affect palliative care knowledge levels.

Conclusion: In the study, it was determined that palliative care knowledge levels of nurses were low and their attitudes toward care giving to terminally ill people were at the medium level.

Keywords: Attitude, death, knowledge, nurses, palliative care
ÖZ

Amaç: Çalışma hemşirelerin palyatif bakım hakkındaki bilgi düzeylerini ve ölmekte olan hasta bakımına ilişkin tutumlarını belirlemek amacıyla yapıldı.

Yöntemler: Tanımlayıcı ve kesitsel özellikte planlanan çalışma, kurum izni ve etik kurul onayı alındıktan sonra, Sakarya İli Kamu Hastaneleri Birliği Genel Sekreterliği' ne bağlı üç hastanede çalışan 350 hemşireyle yapıldı. Sosyo-demografik özellikleri içeren tanıtım formu, Frommelt Ölmekte Olan Bireye Bakım Vermeye İlişkin Tutum ölçeği (FATCOD) ve Palyatif Bakım Bilgi Testi (PBBT) ile toplanan verilerin analizi bilgisayar ortamında yüzdelik, ortalama, Mann-Whitney U, Kruskall-Wallis H ve Pearson's korelasyon testleri kullanılarak yapıldı.

Bulgular: Yaş ortalaması 35,58 7,63 olan hemşirelerin \%84,3'ü kadın, \%60,9'u evli, çoğunluğu lisans mezunu $(\% 51,4)$ ve \%62,9’u dahili birimlerde çalıştığı belirlendi. Hemşirelerin PBBT'den aldıkları ortalama puan $6,35 \pm 3,31$, FATCOD puan ortalaması ise $77,98 \pm 8,81$ olduğu saptandı. Medeni durum, öğrenim düzeyi ve çalışılan birim hemşirelerim ölüme ilişkin tutumlarını etkilemezken palyatif bakım bilgi düzeylerini etkilediği görüldü.

Sonuç: Çalışmada hemşirelerin palyatif bakım bilgi düzeylerinin düşük ve ölmekte olan bireye bakım vermeye ilişkin tutumlarının orta düzeyde olduğu saptandı.

Anahtar Sözcükler: Tutum, ölüm, bilgi düzeyi, hemşireler, palyatif bakım
Address for Correspondence: Ahmet SEVEN, Kahramanmaraş Sütçü İmam University, Afşin School of Health, Division of Nursing, Kahramanmaraş, Turkey

E-mail: ahmetseven@ksu.edu.tr ORCID ID: orcid.org/0000-0002-2599-1918
Received: 24.06 .2019

Accepted: 15.10 .2019

Cite this article as: Seven A, Sert H. How The Nurses' Attitude for Dying Patients and Their Knowledge about Palliative Care. Bezmialem Science 2020;8(3):250-7. 


\section{Introduction}

The World Health Organization defines palliative care as "an effort that improves the quality of life of patients and their families facing problems associated with life-threatening illness, through the prevention and relief of suffering by means of early identification and impeccable assessment and treatment of pain and other problems, physical, psychosocial and spiritual."(1). Palliative care accepts death as a normal part of life and aims at managing how patients actively spend their lives until death. With palliative care, the patient is provided with counseling and a peaceful death in the last moments of life and the family also receives appropriate counseling services (1-3).

The number of people worldwide who are 60 or older is increasing, especially in developed countries. In the 1950s, $8 \%$ of the population were 60 or older population. This is now $12 \%$ and it is predicted that this number will reach $21 \%$ in 2050 (4). Along with the increase of the elderly population, it is thought that chronic diseases will increase and that in 2020, the most common diseases will remain heart diseases, cerebrovascular diseases, chronic respiratory diseases, respiratory infections, and lung cancers (5). The gradual increase in the population of the elderly and chronic diseases around the world ensures that palliative care will retain an important place among medical practices. The aim of the palliative care is to increase the quality of life of individuals suffering chronic diseases that affect their lives and those of their families (6). Recent developments in medical science have increased life spans and delayed times of death. With scientific and medical developments, many diseases have been prevented or their appearance is delayed, but other methods that patients and relatives use in order to ensure survival affect the patients' quality of life negatively (7). In addition to this, multiple problems can occur as a result of a decrease in treatment options and the progression of diseases, inadequate control of pain and other symptoms, and failure to provide the necessary technical support (8). An increase in the treatment options related to a disease or, alternatively, a lack of action may cause problems in terms of the quality of care given to patient in the last stage of their lives. In order to remove or lessen these issues, palliative care is necessary to increase patients' quality of life and for their relatives to develop coping strategies (1). Caring for a dying patient is one of the responsibilities of health professionals, especially nurses, who tend to spend more time with patients. Nurses can be emotionally affected by the process of giving care to terminally ill patients as death generally affects individuals deeply and painfully. Nurses, who are the primary members of the medical team which provides palliative care, are expected to support the patient's family before death and posthumously during the grieving process as well as support their general well-being in psychosocial terms $(9,10)$. In fulfilling these expectations, both the attitudes of nurses towards death and their level of knowledge of palliative care play a huge role. In this context, this study intended to determine the knowledge level of nurses with regard to palliative care and to investigate their attitudes towards terminally ill patients.

\section{Method}

This descriptive and cross-sectional study was conducted between November 2014 and April 2015 after consent had been received from the institution concerned and approval had been given by the Ethics Committee. The study universe was formed of a total of 684 nurses who were working in three major hospitals affiliated to the Public Hospitals Association in the center of Sakarya province: Sakarya Training and Research Hospital (460 nurses), Sakarya Yenikent State Hospital (156 nurses) and Sakarya Toyotasa Emergency Relief Hospital (68 nurses). The research dates and sample formed by these volunteer nurses (350 nurses) were valid in that nurses not on vacation during the research dates the nurses and none of the nurses had any communication problems.

\section{Statistical Analysis}

Data in this research were gathered via a Self-description Form, the Palliative Care Knowledge Test (PCKT) (11) and the Frommelt Attitudes Toward Care Of Dying scale (FATCOD) (12). Data input and evaluation was carried out in a computerized environment. The knowledge levels of nurses regarding palliative care and factors that affected their attitude related to care given to dying patients were presented as percentages and average scores. In comparative statistical analysis, the difference between the averages of the two groups was examined with the MannWhitney $\mathrm{U}$ test, the difference between 3 or more groups was examined with Kruskall-Wallis-H variance analysis, and the relation between the two numerical variables was analyzed with Pearson's correlation test.

\section{Results}

As shown in Table 1, 33.4\% of nurses were between 35 and 44 years old, most nurses were female $(84.3 \%)$ and more than half of them were married (60.9\%). $51.4 \%$ of these nurses were college or university graduates and $62.9 \%$ of them worked in inpatient units. The period of employment of the majority of the participants (35.7\%) was between 1 and 5 years.

It was found that more than half of the nurses had relatively good knowledge about palliative care $(57.7 \%)$ gaining this either while getting their Bachelor's degrees (29.7\%) or from the internet $(17.7 \%)$. When the answers related to palliative care were examined, the most wrongly answered question (57.7\%) was with regard to the statement, "Palliative care is only given to patients in the terminal stage." It was found that most of the nurses $(62.6 \%)$ had given care to a terminally ill patient and/or confronted the concept of death (80.6\%) (Table 2). It was also noted that $93.4 \%$ of the nurses experienced deep sadness while giving care to terminally ill patients and that $32.3 \%$ of them accepted death as a natural process when they first faced the fact of the patients' death (not given in the table).

While no significant statistical difference was found between the marital status of nurses and FATCOD on the one hand, and PCKT Psychiatric Problems sub-dimension scores on the other ( $p>0.05)$, there was a substantial difference between PCKT 
General, Philosophy, Dyspnea $(\mathrm{p}<0.05)$ and Gastrointestinal Problems sub-dimension scores. It was seen that single nurses had PCKT General $(\mathrm{p}<0.01)$, Philosophy $(\mathrm{p}<0.05)$, Dyspnea $(\mathrm{p}<0.05)$ and Gastrointestinal Problems $(\mathrm{p}<0.01)$ sub-dimension average scores that were higher than those of the married ones.

A statistically significant difference was determined between the workplace variable and PCKT general $(\mathrm{p}<0.001)$, philosophy $(\mathrm{p}<0.01)$, pain $(\mathrm{p}<0.01)$ and psychiatric problems $(\mathrm{p}<0.001)$ subdimension scores. According to this result, it was observed that nurses who worked in inpatient units had a greater knowledge of general, philosophy, pain and psychiatric problems subjects related to palliative care than nurses who worked in surgical units (Table 4).

On the other hand, a statistically significant difference was noted between the ages of nurses and the PCKT general $(p<0.01)$, philosophy $(\mathrm{p}<0.01)$ and gastrointestinal problems $(\mathrm{p}<0.01)$ sub-dimension scores. In particular, nurses who were in their mid-twenties and younger had higher scores, but no effect of age was found in relation to Pain, Dyspnea and Psychiatric Problems sub-dimensions and FATCOD scores ( $>$ >0.05)(Table 4).

There was no substantial difference when regard to the education variable and PCKT Philosophy, Gastrointestinal Problems sub-dimension and FATCOD scores $(p>0.05)$. However, a statistically significant difference was found between PCKT

Table 1. Frequency and percent results of the demographic characteristics of the nurses involved in the survey $(n=350)$

\begin{tabular}{|c|c|}
\hline Characteristics & n (\%) \\
\hline \multicolumn{2}{|l|}{ Age } \\
\hline 25 years old and lower & $101(28.9)$ \\
\hline Between 26 - 34 years & $113(32.3)$ \\
\hline Between 35 - 44 years & $117(33.4)$ \\
\hline 45 years old and over & $19(5.4)$ \\
\hline \multicolumn{2}{|l|}{ Gender } \\
\hline Women & $295(84.3)$ \\
\hline Men & $55(15.7)$ \\
\hline \multicolumn{2}{|l|}{ Marital status } \\
\hline Married & $213(60.9)$ \\
\hline Single & $137(39.1)$ \\
\hline \multicolumn{2}{|l|}{ Education level } \\
\hline Vocational health highschool & $79(22.6)$ \\
\hline Associate degree & $91(26.0)$ \\
\hline Bachelor/master degree & $180(51.4)$ \\
\hline \multicolumn{2}{|l|}{ Working unit } \\
\hline Internal units & 220 (62.9) \\
\hline Surgical units & $130(37.1)$ \\
\hline \multicolumn{2}{|l|}{ Vocational working time } \\
\hline Between 1-5 years & $125(35.7)$ \\
\hline Between 6-10 years & $76(21.7)$ \\
\hline Between $11-15$ years & $55(15.7)$ \\
\hline 16 years and over & $94(26.9)$ \\
\hline
\end{tabular}

general, pain, dyspnea and psychiatric problems sub-dimension scores $(\mathrm{p}<0.05)$. It was seen that the PCKT General scores of nurses who had graduated from an HVH (Health Vocational High School) were higher than the PCKT scores of nurses who had an Associate degree. In the sub-dimensions of Dyspnea and

Table 2. Characteristics of palliative care and dying patient care $(n=350)$

\begin{tabular}{|c|c|c|}
\hline Characteristics of palliative ce & e and dying patient care & n (\%) \\
\hline $\begin{array}{l}\text { Knowledge situation } \\
\text { related to palliative care }\end{array}$ & $\begin{array}{l}\text { Yes } \\
\text { No }\end{array}$ & $\begin{array}{l}202(57.7) \\
148 \\
(42.39)\end{array}$ \\
\hline & $\begin{array}{l}\text { Undergraduate } \\
\text { education }\end{array}$ & $104(29.7)$ \\
\hline & Inservice training & $51(14.6)$ \\
\hline Knowledge acquisition & Book and magazines & $27(7.7)$ \\
\hline type* & $\begin{array}{l}\text { Congress/symposium/ } \\
\text { seminar }\end{array}$ & $19(5.4)$ \\
\hline & Internet & $62(17.7)$ \\
\hline & Other & $20(5.7)$ \\
\hline $\begin{array}{l}\text { Statements related to } \\
\text { palliative care }\end{array}$ & Yes & $99(28.3)$ \\
\hline $\begin{array}{l}\mathrm{PC} \text { is only given to cancer } \\
\text { patients }\end{array}$ & No & $251(71.7)$ \\
\hline$P C$ is a treatment that & Yes & $139(39.7)$ \\
\hline time & No & $211(60.3)$ \\
\hline PB is only implemented to & Yes & $202(57.7)$ \\
\hline patients in terminal stage & No & $148(42.3)$ \\
\hline In PC, only paint control is & Yes & $121(34.6)$ \\
\hline done & No & $229(65.4)$ \\
\hline Encountering death & Yes & $282(80.6)$ \\
\hline concept at work & No & $68(19.4)$ \\
\hline Care giving status or dying & Yes & $219(62.6)$ \\
\hline patient & No & $131(37.4)$ \\
\hline
\end{tabular}

Table 3. Distribution of nurses' overall scores of palliative care's general and lower dimensions and attitudes related to the care of the frommelt dying patient $(n=350)$

\begin{tabular}{|c|c|c|}
\hline Scales and sub dimensions & $M \pm S D$ & Min - max point \\
\hline Palliative care general & $6.35 \pm 3.31$ & $0-14$ \\
\hline Philosopy sub dimension & $1.21 \pm 0.82$ & $0-2$ \\
\hline Pain sub dimension & $1.70 \pm 1.09$ & $0-5$ \\
\hline Dyspnea sub dimension & $0.73 \pm 0.88$ & $0-4$ \\
\hline $\begin{array}{l}\text { Psychiatric problems sub } \\
\text { dimension }\end{array}$ & $1.49 \pm 1.01$ & $0-4$ \\
\hline Gastrointestinal problems & $1.20 \pm 0.98$ & $0-4$ \\
\hline $\begin{array}{l}\text { Frommelt attitudes toward } \\
\text { care of dying scale }\end{array}$ & $77.98 \pm 8.81$ & $54-100$ \\
\hline
\end{tabular}


Psychiatric Problems, it was determined that $\mathrm{HVH}$ graduate nurses had higher scores than nurses who had Bachelor's and associate degrees. It was noted that the period of professional employment affected the PCKT general, philosophy, dyspnea and gastrointestinal problems sub-dimension scores in a statistically meaningful way $(\mathrm{p}<0.01)$, and that nurses who had worked for 1 to 5 years had higher average scores than those who had worked for 16 years and over. Educational level and period of employment were determined to have no effect on the attitudes of nurses towards the care of terminally ill patients (Table 4).

Nurses who had encountered death in the units where they worked had better knowledge levels in the palliative care general, pain and dyspnea sub-dimensions $(\mathrm{p}<0.05)$; those who provided care to terminally ill patients also had better knowledge levels in the PCKT General $(\mathrm{p}<0.01)$, Philosophy $(\mathrm{p}<0.01)$, Pain $(\mathrm{p}<0.01)$, Psychiatric Problems $(\mathrm{p}<0.001)$ and Gastrointestinal Problems

Table 4. Attitude and palliative care knowledge level on the dying care according to socio-demographic characteristics $(n=350)$

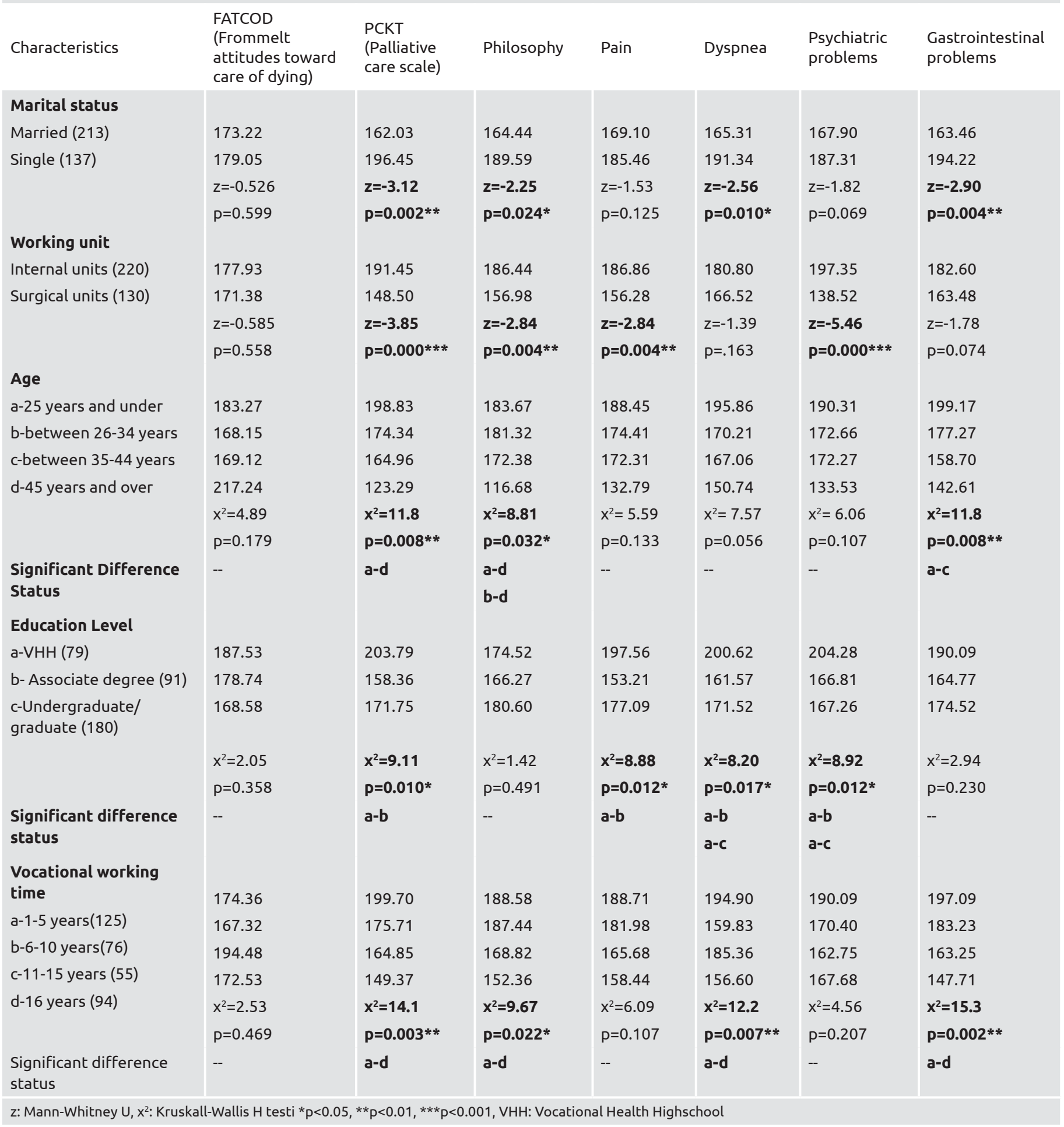


$(\mathrm{p}<0.01)$ Sub-dimensions, and those who had encountered death in their inner circle (family, relative, friend) had better knowledge in the PCKT general $(\mathrm{p}<0.01)$, pain, dyspnea and gastrointestinal problems sub-dimensions $(\mathrm{p}<0.05)$ (Table 5). It was determined that these variables did not affect their attitudes towards the care of terminally ill patients $(\mathrm{p}>0.05)$.

Meanwhile, it was found that nurses who saw palliative care as only applying to patients with cancer had lower knowledge levels in the PCKT general $(\mathrm{p}<0.01)$, philosophy $(\mathrm{p}<0.01)$, pain $(\mathrm{p}<0.01)$ and dyspnea $(\mathrm{p}<0.05)$ sub-dimensions, but they had more positive attitudes towards the care of terminally ill patients $(\mathrm{p}<0.001)$.

It was determined statistically that the scores of nurses who stated that palliative care is only given to patients who are in the terminal stage were significantly lower in the PCKT general $(\mathrm{p}<0.05)$, philosophy $(\mathrm{p}<0.05)$ and pain $(\mathrm{p}<0.01)$ sub-dimensions than the scores of those who did not think that it only to be given to patients in the terminal stage.

\section{Discussion}

Palliative care is a service that provides effective symptom management with the aim of improving the quality of life. The duty of providing effective palliative care basically falls to nurses.
In order to carry out these responsibilities, a necessary level of knowledge about palliative care is expected from nurses. In many studies conducted, it has been found that nurses who work in multidisciplinary teams with a caring focus, do not have enough knowledge of palliative care (13-19). In this study, too, it was found that similar nurses did not have enough knowledge of palliative care (Table 3).

One of the most powerful aspects of nursing is encountering death and providing care to near-death patients. Nurses encounter death in settings where, on the one hand, they have to provide continuous professional nursing care, while on the other coping with the fact of death emotionally. Every individual's reaction towards death, as well as in caring for terminally ill patients, differs significantly according to one's personal attitude (7). Attitudes concerning the care of terminally ill patients affect the quality of care which nurses provide $(9,20,21)$. In this study, the FATCOD average score $(77.98 \pm 8,81)$ which shows attitudes towards the care of dying patients was found to be lower than in other studies conducted on the basis of FATCOD average scores (22-25). We think that this situation is due to cultural differences as well as educational differences in relation to end-of-life care and palliative care.

Table 5. Attitudes and palliative care knowledge level related to dying care according to features related to the concept of palliative care and dying patient care $(n=350)$

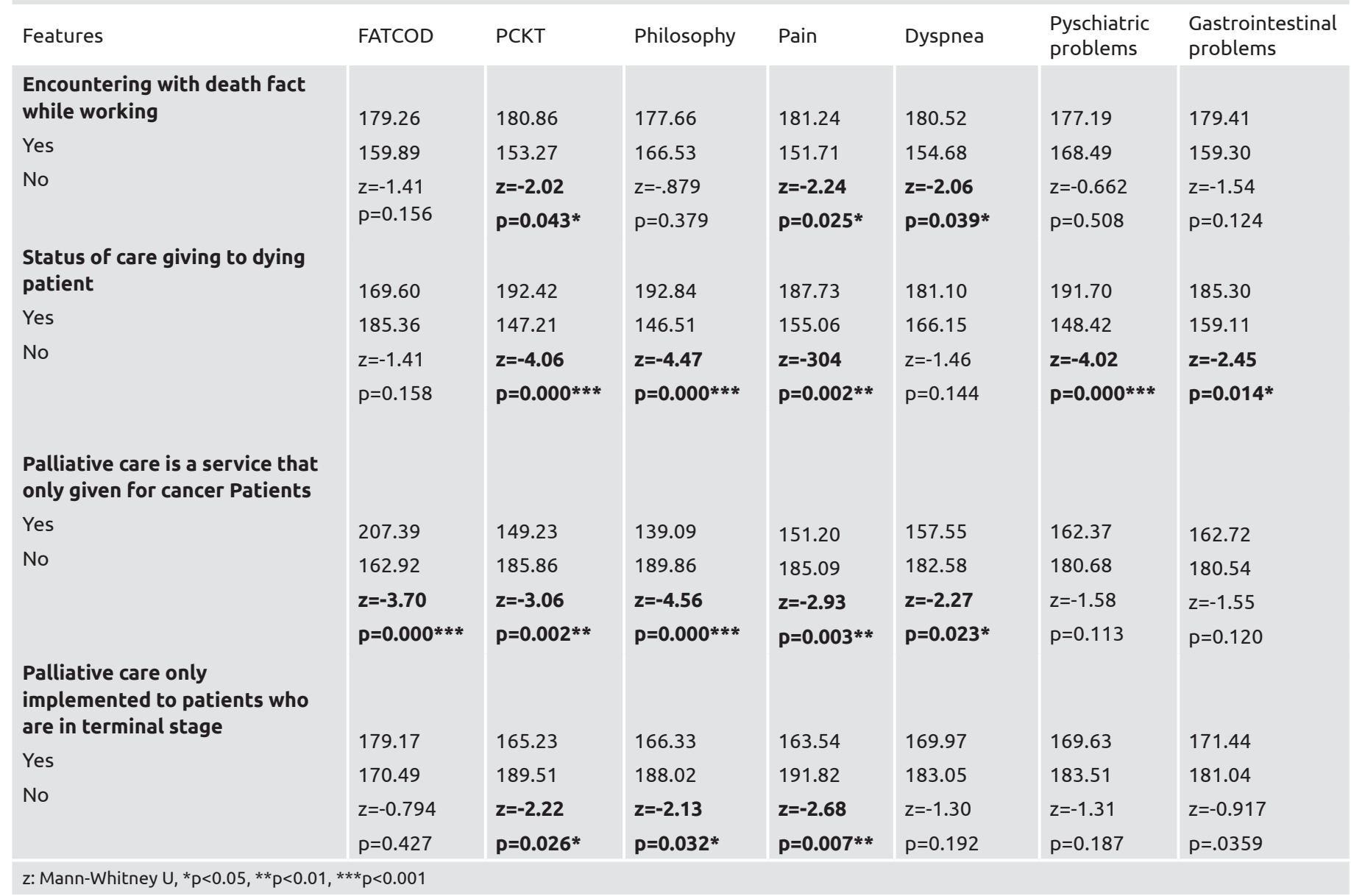


In the studies conducted, no significant difference was found between knowledge of palliative care, attitudes towards giving care to the dying patient and the variable of gender $(13,16,19,22-26)$. Likewise, in the pertinent literature, no statistically significant difference was found between genders in terms of FATCOD, PCKT general and sub-dimension scores $(p>0.05)$. A statistically significant difference was found between the marital status of nurses and PCKT general, philosophy, dyspnea and gastrointestinal problems sub-dimension scores. It was observed that single nurses had significantly higher PCKT general, philosophy, dyspnea and gastrointestinal problems sub-dimensions average scores than married ones (Table 4). We think that the reason for the higher PCKT scores is that most of the single nurses are younger and had less experience after their graduation, and that in recent years training related to palliative care has been included in the education curricula.

A statistically significant difference was detected between the place of employment variable and PCKT general, philosophy, pain and psychiatric problems sub-dimensions. Accordingly, it was observed that the knowledge of nurses who worked in inpatient units related to general, philosophy, pain and psychiatric problems was higher than that of those who worked in surgical units (Table 4). This situation may be due to the fact that those nurses deal with patients who stay longer in the clinics and have diseases that need palliative care. Similarly, in another study conducted, it was observed that nurses who worked in inpatient units had a better knowledge of palliative care (19).

In addition, in this study, a statistically significant difference was found between the variable of age and PCKT general, philosophy, gastrointestinal problems sub-dimension scores. By contrast, there was no statistically significant difference between pain, dyspnea and psychiatric problems sub-dimensions and FATCOD scores ( $p>0.05)$. According to this result, nurses in the 25 years or younger age group had higher PCKT average scores (Table 4). When the literature was examined, it was determined that this was similar to another study in which nurses under 29 years had higher PCKT average scores (11). In other studies, age did not affect level of knowledge of palliative care $(16,17,19)$. It can be concluded that the reason for this difference is due to the relative novelty of the concept of palliative care and its recent inclusion in training, which results in the younger group having a higher level of awareness. Again, in studies similar to this current study, it was seen that age did not affect FATCOD scores $(22,27)$.

In the study, it was determined that educational level did not affect PCKT philosophy, gastrointestinal problems sub-dimensions and FATCOD scores. However, it affected PCKT general, pain, dyspnea and psychiatric problems. Nurses who graduated from an VHH (Vocational Health Highschool) were found to have higher scores in comparison to nurses with Bachelor's and associate degrees (Table 4). In the study by Nakazawa et al. (11), it was also found that the PCKT scores of nurses who graduated from high schools were similar to those in the current study. In another study, it was observed that the average score of Associate degree graduates was higher than that of undergraduates and high school graduates (26). On the other hand, in many studies a positive relationship was determined between the educational level of nurses and their knowledge of palliative care (28-30). The reason for the higher scores of the $\mathrm{HVH}$ graduates in the present study is probably due to the fact that they had worked longer in the clinic, especially in the inpatient clinics, than those graduates with Associate and Bachelor's degrees. It was also determined that in other studies conducted to determine attitudes related to providing care to dying patients, educational status did not affect the attitudes of the nurses, and this shows parallelism with the present study $(27,31)$.

While there was a statistically significant difference $(\mathrm{p}<0.01)$ between the duration of professional employment and PCKT general, philosophy, dyspnea and gastrointestinal problems subdimension scores, no significant difference was found between the other variables and FATCOD scores. Statistically, the nurses who had worked for 1-5 years were found to have higher scores on the PCKT general philosophy, dyspnea and gastrointestinal problems subscales than nurses working in this area for 16 years or more (Table 4). In another study, it was determined that nurses with less than 4 years of working experience had a better knowledge of palliative care (11). Similarly in another study, less experienced nurses (1-10 years) were found to be more knowledgeable about palliative care than those with 10-20 years of experience (15). In a similar study, it was seen that the duration of professional employment (FATCOD) did not affect attitudes related to providing care to terminally ill patients (24).

In the current study, it was determined that the variable of "experiencing death in the work place" affected the scores for the General, Pain and Dyspnea sub-dimensions related to palliative care $(\mathrm{p}<0.05)$. Those who had provided care to terminally ill patients had higher PCKT general, philosophy, pain, psychiatric problems and gastrointestinal problems sub-dimension scores that were statistically significant, compared to those who had not provided such care (Table 5). In many other studies, a positive relationship was determined between knowledge of palliative care and nurses' having encountered death, and having provided care to terminally ill patients $(11,15,26,28,30)$. It is thought that experiences that gained through providing end-of-life care, which is part and parcel of palliative care, positively affect the nurses' level of knowledge and this tallies with the results of the current study. In a different study, it was seen that nurses who had encountered terminally ill patients and provided care to them had higher FATCOD scores than those who did not have such experience (25). It is thought that this difference is due to the fundamental differences found in the environments in which individuals live, receive education, work and provide this kind of care.

\section{Conclusion}

The main findings of this study, conducted to determine nurses' levels of knowledge and their attitudes towards providing care to terminally ill patients, are: 
- Nurses were found to have a low level of knowledge of palliative care. However, their attitudes towards providing care to terminally ill patients were found to be positive.

- Taking into consideration the socio-demographic characteristics, marital status, education level, employment period and working unit, it was determined that having encountered death and provided care to terminally ill patients affected nurses' knowledge of palliative care, whereas it did not affect their attitudes when it came to providing care to terminally ill patients.

\section{In light of these findings:}

- There should be a constant evaluation of health professionals' levels of knowledge of palliative care and their attitudes towards providing care to terminally ill patients as well as the factors affecting these.

- Effective undergraduate or postgraduate education programs should be implemented in order to eliminate any inadequacies in knowledge of palliative care and develop positive attitudes towards death.

\section{Ethics}

Ethics Committee Approval: This study was approved by the Ethics Committee of Faculty of Medicine of Sakarya University, Approval no.71522473/050.01.04/113.

Informed Consent: Written informed consent was not received due to the nature of this study.

Peer-review: Externally peer-reviewed.

\section{Authorship Contributions}

Concept: A.S., H.S., Design: A.S., H.S., Data Collection or Processing: A.S., H.S., Analysis or Interpretation: A.S., H.S., Literature Search: A.S., H.S., Writing: A.S., H.S.

Conflict of Interest: No conflict of interest was declared by the authors.

\section{References}

1. World Health Organization. Who definition of palliative care. Available URL: http:/www.who.int/cancer/palliative/definition/en/

2. Özkan S. Palliative and The End-Life Care in the Chronic Obstructive Lung Disease. Selçuk Tip Derg. 2011;28:69-74.

3. Worldwide Palliative Care Alliance. (2013). Defining palliative care. Available URL: http://www.thewhpca.org/resources/item/defingingpalliative-care

4. Department of Economic and Social Affairs Population Division. World Population Ageing 2013. [Cited: 21 March 2015.] Available URL:http://www.un.org/en/development/desa/population/ publications/pdf/ageing/WorldPopulationAgeing2013.pdf

5. Murray CJL, Lopez AD. Alternative projections of mortality and disability by causes 1990-2020: Global burden of disease study. Lancet 1997;349:1498-504.
6. Sepúlveda C, Marlin A, Yoshida T, Ullrich A. Palliative Care: The World Health Organization's global perspective. Journal of Pain and Symptom Management 2002;24:91-6.

7. İnci F, Öz F. Palliative care and death anxiety. Current Approaches in Psychiatry 2012; 4:178-87.

8. Elçigil A. Palliative care nursing. Gulhane Med J 2012;54: 329-34.

9. Eues SK. End-of-life care; improving quality of life at the end of life. Professional Case Management 2007;12:339-44.

10. Brosche TA. A grief team within a healthcare system. Dimens Crit Care Nurs 2007;26:21-8.

11. Nakazawa Y, Miyashita M, Morita T, Umeda M, Oyagi Y, Ogasawara T. The palliative care knowledge test: reliability and validity of an instrument to measure palliative care knowledge among health professionals. Palliative Medicine 2009;00:1-12.

12. Frommelt K. Attitudes toward care of the terminally ill: an educational intervention. Am J Hosp Palliat Care 2003;20:13-22.

13. Prem V, Karvannan H, Kumar SP, Karthikbabu S, Syed N, Sisodia V, et al. Study of nurses' knowledge about palliative care: a quantitative cross-sectional survey. Indian Journal of Palliative Care 2012;18:1227.

14. Ayed A, Sayej S, Harazneh L, Fashafsheh I, Eqtait F. The nurses' knowledge and attitudes towards the palliative care. Journal of Education and Practice 2015;6:91-9.

15. Youssef HAM, Mansour MAM, Al-Zahrani SSM, Ayasreh IRA, Abd El-Karim RAK. Prioritizing palliative care: Assess undergraduate nursing curriculum, knowledge and attitude among nurses caring end-of-life patients. European Journal of Academic Essays 2015;2:90101.

16. Iranmanesh S, Razban F, Tirgarı B, Zahra G. Nurses' knowledge about palliative care in Southeast Iran. Palliative and Supportive Care 2014;12:203-10.

17. Al Qadire M. Knowledge of palliative care: an online survey. Nurse Education Today 2014;34:714-8.

18. Al Qadire M. Nurses' knowledge about palliative care: a cross-sectional survey. Journal of Hospice \& Palliative Nursing 2014;16:23-30.

19. Kassa H, Murugan R, Zewdu F, Hailu M, Woldeyohannes D. Assessment of knowledge, attitude and practice and associated factors towards palliative care among nurses working in selected hospitals, Addis Ababa, Ethiopia. BMC Palliat Care 2014;13:6.

20. Yilmaz M. Experiences of loss: a case study. Maltepe Üniversitesi Hemşirelik Bilim ve Sanatı Dergisi 2010;2:150-5.

21. Çavdar I. Care of the cancer patient in the terminal period. Turk Onkoloji Dergisi 2011;26:142-7.

22. Arslan D, Kilic N, Simsek N, Zorba P. Student nurses' attitudes toward dying patients in Central Anatolia. International Journal of Nursing Knowledge 2014;25:183-8.

23. Dunn KS, Otten C, Stephens E. Nursing experience and the care of dying patients. Oncology Nursing Forum 2005;32:97-104.

24. Ho T, Barbero E, Hidalgo C, Camps C. Spanish nephrology nurses' views and attitudes towards caring for dying patients. J Ren Care 2010;36:2-8. 
25. Leombruni P, Miniotti M, Bovero A, Zizzi F, Castelli L, Torta R. Attitudes toward caring for dying patients: An overview among Italian nursing students and preliminary psychometrics of the FATCOD-B scale. Journal of Nursing Education and Practice 2014;4:188-96.

26. Sato K, Inoue Y, Umeda M, Ishimagori I, Igarashi A, Togashi S, et al. A Japanese region-wide survey of the knowledge, difficulties and self-reported palliative care practices among nurses. Japanese Journal of Clinical Oncology 2014; hyu075.

27. Wessel EM, Rutledge DN. Home care and hospice nurses' attitudes toward death and caring for the dying: Effects of palliative care education. Journal of Hospice \& Palliative Nursing 2005;7:212-8.

28. Knapp CA, Madden V, Wang H, Kassing K, Curtis C, Sloyer P, et al. Paediatric nurses' knowledge of palliative care in Florida:
A quantitative study. International Journal of Palliative Nursing 2009; 15: 432-9.

29. Huijer HAS, Dimassi H, Abboud S. Perspectives on palliative care in Lebanon: Knowledge, attitudes, and practices of medical and nursing specialties. Palliative and Supportive Care 2009;7:339-47.

30. Ronaldson S, Hayes L, Carey M, Aggar C. A study of nurses' knowledge of a palliative approach in residential aged care facilities. International Journal of Older People Nursing 2008;3:258-67.

31. Conner NE, Loerzel VW, Uddin N. Nursing student end-of-life care attitudes after an online death and dying course. Journal of Hospice \& Palliative Nursing 2014;16:374-82. 